\title{
Equilibrium
}

Quarterly Journal of Economics and Economic Policy

VOLUME 8 ISSUE 3, 2013

ISSN 1689-765X, (Online) ISSN 2353-3293

http://www.equilibrium.umk.pl/

Baran K.A. (2013), The Determinants of Economic Growth in Hungary, Poland, Slovakia and the Czech Republic During the Years 1995-2010, "Equilibrium. Quarterly Journal of Economics and Economic Policy", Volume 8, Issue 3, pp. 7-26, DOI: http://dx.doi.org/10.12775/EQUIL.2013.017

Katarzyna Anna Baran*

Technische Universität Darmstadt, Germany

\section{The Determinants of Economic Growth in Hungary, Poland, Slovakia and the Czech Republic During the Years 1995-2010}

JEL Classification: $125,011,030,047$

Keywords: determinants of economic growth, transition economies of Central Eastern Europe, Sollow growth accounting, non-parametric growth accounting

\begin{abstract}
The main goal of the research is to obtain a comprehensive examination of the economic growth determinants in Hungary, Poland, Slovakia and the Czech Republic (CEEC-4) since 1995. For this purpose, two methodological approaches have been applied: the Solow growth accounting and the non-parametric approach. At the beginning of the analysis, in order to obtain a general overview of the sources of economic growth in the former transition countries of Central Eastern Europe, the Solow growth accounting has been conducted. It decomposes the growth rate of output into contributions from changes in the quantity of the physical capital stock, the amount of labour input and some other unexplained factor commonly interpreted as reflecting technological progress and called the "Solow residual" or "Total Factor Productivity (TFP)". The hypothesis that technological progress together with strong capital accumulation were the dominant factors behind the economic growth and convergence process in the Central Eastern European countries before the crisis is tested. As the Solow growth accounting does not reveal the driving forces behind the technological progress and, thus, a large part of the growth decomposition remains unexplained in the transition economies, the non-parametric ap-
\end{abstract}

\footnotetext{
(C) Copyright Institute of Economic Research \& Polish Economic Society Branch in Torun Date of submission: March 18, 2013; date of acceptance: June 17, 2013

* Contact: kbaran64@gmail.com, Technische Universität Darmstadt, Karolinenplatz 5, 64289 Darmstadt, Germany
} 
proach has been employed to shed more light on the ultimate sources of economic growth in the CEEC-4. The non-parametric (production-frontier) method enables the further decomposition of changes in total factor productivity into changes in the efficiency of production and technological changes. Furthermore, it allows accounting for human capital accumulation, since improvements in quality of labour are also reflected in TFP growth.

\section{Introduction}

Since the beginning of its transition in the early 1990s, the Central Eastern European countries (CEEC) have seen impressive progress. In a span of less than two decades, the region went from socialist centrally-planned economies to fully-fledged market economies (Åslund 2007). This economic transformation, accompanied by extensive structural changes, boosted growth, and after an initial decline in output, emerging Europe grew faster than almost all other emerging market regions, allowing it to display real convergence. Figure 1 shows that per capita income expanded by 4 percent annually from 1995 to 2007 - exceeded only by China and India (Bakker and Klingen 2012, p. 3; Čihák and Fonteyne 2009). This rapid growth also allowed the CEEC to increase their share in the world's economic output, which has been increasing from about $1.5 \%$ in the early 1990 s to an estimated $2.1 \%$ in $2008 .^{1}$

Having followed their economic transformation - marked by the accession to the European Union (EU) in 2004 - the CEEC countries recorded, however, heterogeneous growth paths. The focus of my study is the analysis of main growth determinants in four Central Eastern European countries: Hungary, Poland, Slovakia and the Czech Republic (henceforth the CEEC-4) since 1995 till 2010. The choice of those countries is determined by their direct geographical proximity with Western Europe, in particular with its most advanced economy - Germany, and their adoption of different approaches in conducting market reforms. While all four countries under discussion followed a set economic policy prescriptions promoted by international institutions (the so called Washington Consensus) ${ }^{2}$ aimed at macroeco-

${ }^{1}$ Analysing economies' shares in the world economic output is useful, because - unlike the GDP growth rates - these shares are not affected by the global economic cycle.

${ }^{2}$ In addition, the Washington Consensus highlighted the importance of property rights protection and enforcement of contracts as essential preconditions for entrepreneurship and growth. A recent augmented Washington Consensus commissioned by the World Bank, known as the Spence Report, put forward policy recommendations that are more microoriented than the initial version, and take into account the different circumstances faced by countries or regions. It emphasizes the common role that education, corporate governance, anti-corruption, competition and labour market mobility play in fostering growth across 
nomic stabilization, trade liberalization and privatisation, Poland and the former Czechoslovakia (Commission on Growth and Development 2008) ${ }^{3}$ adopted a more radical reform program, while Hungary opted for a more gradual approach to reforms.

Figure 1. Emerging Europe and Selected Regions: Real Per Capita GDP Growth, 1995-2007 (annual percentage change in purchasing power parity terms)

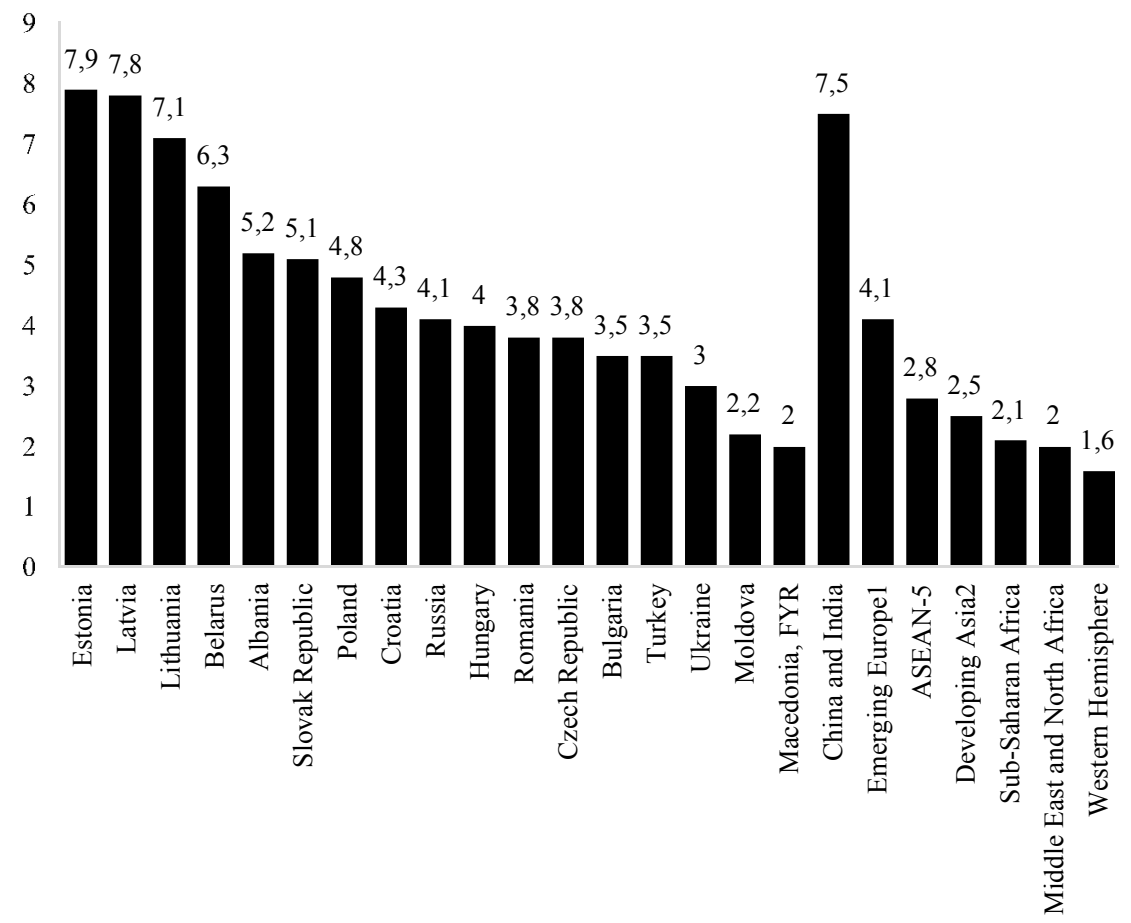

Note: ASEAN-5 = Five of the members countries of the Association of Southeast Asian Nations, including Indonesia, Malaysia, the Philippines, Thailand and Vietnam.

${ }^{1}$ Includes the Czech Republic and the Slovak Republic.

${ }^{2}$ Excludes China and India.

Source: IMF World Economic Outlook database in Bakker and Klingen (2012).

a wide range of countries, and stresses the importance of government commitment to pursuing growth-enhancing policies in the long term.

${ }^{3}$ A peaceful separation of the Czechoslovakia, known as the Velvet Divorce, into two independent states - the Czech Republic and the Slovak Republic - took place on January 1, 1993. 
The radical reforms were aimed at putting hyperinflation to a halt by tightening monetary policy, and at a swift reduction of large budget deficit. The program also envisaged the convertibility of currency on the current account to allow for free trade and for the breaking up of monopolies to avoid monopolistic pricing. Restrictions on the private sector had to be abolished and new private entrepreneurs were to be offered a maximum of freedom. On the other hand, the proponents of more gradual economic reforms favored state intervention and retained a strong belief in social engineering. Also, gradualists wanted to stimulate output through demand management (whereas radical reformers saw a systemic lack of supply as the prime problem). Therefore, they defended the Hungarian policies against the Polish shock therapy (Åslund 2007, p. 32, 37).

The time span of research will encompass the years from 1995 (when these countries passed beyond their lowest output levels since the economic transformation) till 2010. Almost two decades provide a sufficient framework for studying growth determinants in the region. The recent global financial and economic crisis has revealed many serious vulnerabilities of the Central Eastern European economies, and provides a ground for rethinking the growth strategies in the region, which should focus even more on growth-enhancing economic and structural policies. The main goal of the research is to obtain a comprehensive examination of the economic growth determinants in Hungary, Poland, Slovakia and the Czech Republic since 1995.

\section{Methodology of the Research}

For this purpose, two methodological approaches have been applied: the Solow growth accounting and the non-parametric approach. At the beginning of the analysis, in order to obtain a general overview of the sources of economic growth in the former transition countries of Central Eastern Europe, the Solow growth accounting has been conducted. ${ }^{4}$ It decomposes the growth rate of output into contributions from changes in the quantity of the physical capital stock, the amount of labour input and some other unexplained factor commonly interpreted as reflecting technological progress and called the "Solow residual" or "Total Factor Productivity (TFP)". The aim is to obtain an insight into the general importance of physical capital accu-

\footnotetext{
${ }^{4}$ Solow growth accounting is a framework developed to test empirically the neoclassical growth model by Solow (1956) and Swan (1956).

${ }^{5}$ TFP is measured as the 'residual' part of total output growth not explained by capital and labour. Its measurement is more difficult for the transition countries than for advanced economies, due to the lack of reliable capital stock data.
} 
mulation and technological progress in the production process in the CEEC4 before analyzing in detail by what factors this process was driven. The hypothesis of the paper is the following: technological progress together with strong capital accumulation were the dominant factors behind the economic growth and convergence process in Central Eastern European countries before the crisis.

Two different models have been estimated, depending on the data specification. The first one is based on the standard model of Solow growth accounting and uses "the total amount of working hours" as a more accurate measure of labour input instead of "total employment". The total amount of working hours in the economy is the number of hours worked by all selfand dependent employed individuals. As the data on working hours is only available for people in dependent employment, in order to compute the amount of working hours for all employed persons the fraction of selfemployed persons in total employment has been computed. It has also been assumed that the self-employed work the same amount of hours as the dependently employed and the figures have been scaled up accordingly (Neuhaus 2006, p. 13). In the second model, the relative rather than the absolute contributions of each input factor to economic growth have been measured. The Sollow growth decomposition has been conducted for the CEEC-4, as well as for Germany and the US as benchmark advanced economies, for comparative purpose. The data for estimations has been taken from the OECD Economic Outlook and the Groningen Growth and Development Centre (GGDC) Total Economy databases.

\section{Sollow growth accounting}

The Solow decomposition is built, as in Neuhaus (2006), on the standard neoclassical production function, where output of period $t, Y_{t}$, is produced by a combination of capital $\mathrm{K}_{\mathrm{t}}$ and labour $\mathrm{L}_{\mathrm{t}}$. $\mathrm{A}_{\mathrm{t}}$ ("Total Factor Productivity", TFP) represents the level of "technology" in the economy:

$$
Y_{t}=A_{t} F\left(K_{t}, L_{t}\right)
$$


The growth rate of output will be derived by taking logarithms on both sides, and then by differentiating the production function with respect to time (for simplicity the time indices were dropped) ${ }^{6}$ :

$$
\frac{\dot{Y}}{Y}=\frac{\dot{A}}{A}+\left(\frac{A F_{\mathrm{K}} K}{Y}\right) \cdot \frac{\dot{K}}{K}+\left(\frac{A F_{L} L}{Y}\right) \cdot \frac{\dot{L}}{L}
$$

$F_{K}$ and $F_{L}$ denote the partial derivatives of $F(\cdot)$ with respect to $\mathrm{K}$ and $\mathrm{L}$. Hence the growth rate of output consists of the growth rate of TFP and the weighted average of the growth rates of the two input factors. Under the assumption of perfect competition on the factor markets, i.e. if both factors are paid their marginal product, $A F_{K}=r$ and $A F_{L}=w$, then $A F_{K} K / Y$ is the share of capital income and $A F_{L} L / Y$ is the share of labour income in total income. Due to the Inada conditions the production function exhibits constant returns to scale, so that the two income shares sum up to 1 . If we let $\alpha$ be the capital income share, then we can rewrite equation (2) as:

$$
\frac{\dot{Y}}{Y}=\frac{\dot{A}}{A}+\alpha \cdot \frac{\dot{K}}{K}+(1-\alpha) \cdot \frac{\dot{L}}{L}
$$

TFP and its change over time will be computed as the residual of equation (3). For the empirical analysis, the equation needs to be reformulated in discrete time. As annual data and most quantities are given as "end of period" figures, using Thörnqvist's approach, the growth figures in period $t+1$ will be associated with the income shares in period $t+1$ :

$$
\frac{Y_{t+1}-Y_{t}}{Y_{t}}=\left(\frac{A_{t+1}-A_{t}}{A_{t}}\right)+\alpha_{t+1}\left(\frac{K_{t+1}-K_{t}}{K_{t}}\right)+\left(1-\alpha_{t+1}\right) \frac{L_{t+1}-L_{t}}{L_{t}}
$$

This is the standard model of Solow growth accounting, which allows for variations in the factor income shares $\alpha_{t+1}$ and $\left(1-\alpha_{t+1}\right)$, as it is built on the standard neoclassical production function. ${ }^{7}$ In addition to the analysis of the absolute contributions, the relative contributions of each factor input to

\footnotetext{
${ }^{6} \mathrm{~A}$ dot on a variable indicates changes of the variable over time.

${ }^{7}$ This, however, would not be valid under the assumption of a Cobb-Douglas production function, which assumes an exact relationship between output and inputs, i.e. $F\left(K_{t}, L_{t}\right)=$ $K_{t}^{\alpha} L^{1-\alpha}$, and assumes constant factor income shares, $\alpha$ and $(1-\alpha)$.
} 
economic growth have also been computed. This provides an insight of the relative importance of each factor in the production process.

\section{Non-parametric growth accounting}

As the Solow growth accounting does not reveal the driving forces behind the technological progress and, thus, a large part of the growth decomposition remains unexplained in the transition economies, the non-parametric approach has been employed to shed more light on the ultimate sources of economic growth in the CEEC-4. The non-parametric (production-frontier) method enables the further decomposition of changes in total factor productivity into changes in the efficiency of production and technological changes. Furthermore, it allows accounting for human capital accumulation since improvements in quality of labour are also reflected in TFP growth. As the stock of human capital (proxied by school enrollment ratios) inherited from the centrally-planned economies was very high in Central Eastern Europe, it is important to account for this factor. For a given level of initial per capita income, a higher initial stock of human capital tends to generate higher economic growth through at least two channels. First, more human capital facilitates the absorption of superior technologies from developed countries. Secondly, the countries which start with a high ratio of human to physical capital - such as the transition economies in the aftermath of the sharp drop in output and physical capital in the early 1990s - tend to grow rapidly by adjusting upward the quantity of physical capital (Iradian 2007, p. 21).

Labour productivity growth is decomposed into technological change (shifts in the world production frontier), efficiency change (movements toward or away from the frontier), and physical and human capital accumulation (movements along the frontier). This quadripartite decomposition is carried out based on data envelopment analysis (DEA) introduced by Farrell (1957) and exposited by Färe et al (1994), and on the methodology developed by Kumar and Russell (2002), and Henderson and Russell (2005). The authors construct a deterministic frontier for the sample, and compare each country's distance from the frontier in a framework of constant returns to scale. They use distance functions to calculate the Malmquist index as an alternative measure of TFP. So far, no studies have been conducted for the former transition economies of Central Eastern Europe using the quadripartite decomposition. Therefore, the research is precursory is this regard as the sample consisting of 35 countries - aside from advanced and developing economies - includes 12 post-transition countries mainly from Central East- 
ern Europe. ${ }^{8}$ The choice of countries and the time frame was conditioned on the availability of data.

The production-frontier approach is a non-parametric estimation of the technology through enveloping the data by the smallest convex free disposable cone of the observed data on inputs and outputs, the upper boundary of which would be the observed "best-practice" world production frontier. Technology contains, as in Henderson and Russell (2005), four macroeconomic variables: aggregate output and three aggregate inputs - labor, physical capital, and human capital. Let $\left\langle Y_{n t}, L_{n t}, K_{n t}, H_{n t}\right\rangle, t=1, \ldots, T ; n=1$, ..., $N$ represent $T$ observations on these four variables for each of the $N$ countries. Following macroeconomic literature, it is assumed that human capital enters the technology as a multiplicative augmentation of physical labor input, so that our $N T$ observations are $\left\langle Y_{n t}, \hat{L}_{n t}, K_{n t}\right\rangle, t=1, \ldots, T ; n=1, \ldots$, $N$; where $\widehat{L}_{n t}=H_{n t} L_{n t}$ is the amount of labour input measured in efficiency units in country $\mathrm{n}$ at time t.

The approach to constructing the frontier follows Kumar and Russell (2002) methodology, which does not preclude implosion of the frontier over time. The technology set is estimated under the assumption of constant returns to scale:

$$
\begin{gathered}
T_{t}=\left\{\left\langle Y_{t}, \hat{L}_{t}, K_{t}\right\rangle: \sum_{n=1}^{N} z_{n t} K_{n t} \leq K_{t},\right. \\
\sum_{n=1}^{N} z_{n t} \hat{L}_{n t} \leq \widehat{L}_{t}, \\
\sum_{n=1}^{N} z_{n t} Y_{n t} \geq Y_{t}, \\
\left.z_{n t} \geq 0, \mathrm{n}=1, \ldots, \mathrm{N}\right\}
\end{gathered}
$$

where $z_{n t}, n=1, \ldots, N$ are Intensity Variables, one for every activity and for time period. These variables are non-negative real numbers and they indicate to what extent a particular activity is involved in turning inputs into outputs.

The Farrel (output-based) efficiency index for a country $\mathrm{n}$ at time $\mathrm{t}$ is defined as in Henderson and Russell (2005) by:

$$
\mathrm{E}\left(Y_{n t}, \hat{L}_{n t}, K_{n t}\right)=\min \left\{\lambda \mid\left\langle\frac{Y_{n t}}{\lambda}, \hat{L}_{n t}, K_{n t}\right\rangle \in T_{t}\right\}
$$

\footnotetext{
${ }^{8}$ The sample size will be extended in the coming year, as more data becomes available.
} 
This index is the inverse of the maximal proportional amount that output $Y_{n t}$ can be expanded while remaining technologically feasible, given the technology $T_{t}$ and the input quantities $\hat{L}_{n t}$ and $K_{n t}$. It is less than or equal to 1 and takes the value of 1 if and only if the $n t$ observation is on the period- $t$ production frontier.

In the quadripartite decomposition, the growth of output per efficiency unit of labor is broken down into the components: technological change, efficiency change, capital deepening (increases in the capital-labor ratio) and human capital accumulation. Letting $\mathrm{b}$ and $\mathrm{c}$ stand for the base period and the current period, respectively, by definition, potential (production-frontier) outputs per efficiency unit of labor in the two periods are given by $\bar{y}_{b}\left(\hat{k}_{b}\right)=$ $\frac{\hat{y}_{b}}{e_{b}}$ and $\bar{y}_{c}\left(\hat{k}_{c}\right)=\frac{\hat{y}_{c}}{e_{c}}$, where $e_{b}$ and $e_{c}$ are the values of the efficiency indexes in the respective periods. Therefore:

$$
\frac{\hat{y}_{c}}{\hat{y}_{b}}=\frac{e_{c} \bar{y}_{c}\left(\hat{k}_{c}\right)}{e_{b} \bar{y}_{b}\left(\hat{k}_{b}\right)}
$$

Now $\tilde{k}_{c}=\frac{K_{c}}{L_{c} H_{b}} \quad$ can be defined (the ratio of capital to labor measured in efficiency units under the counterfactual assumption that human capital had not changed from its base period level), as well as $\tilde{k}_{b}=\frac{K_{b}}{L_{b} H_{c}}$ (the counterfactual capital/efficiency-labor ratio in the base period if human capital were equal to its current-period level). Let $\bar{y}_{b}\left(\tilde{k}_{c}\right)$ and $\bar{y}_{c}\left(\tilde{k}_{b}\right)$ denote potential output per efficiency unit of labor at $\tilde{k}_{c}$ and $\tilde{k}_{b}$ using the base-period and current period technologies, respectively.

The growth of productivity, $y_{t}=\frac{Y_{t}}{L_{t}}$, can be decomposed into the growth of output per efficiency unit of labor and the growth of human capital, as follows:

$$
\frac{y_{c}}{y_{b}}=\frac{H_{c}}{H_{b}} \cdot \frac{\hat{y}_{c}}{\hat{y}_{b}}
$$

As technological change is not Hicks neutral, the decomposition of productivity changes is path dependent and does not yield the same results. Following Färe et al. (1994), and more recent research by Kumar and Russell (2002), Henderson and Russell (2005) adopt the "Fischer ideal" decomposition, based on geometric averages of the two measures of the effects of 
technological change and physical and human capital accumulation, obtained by multiplying top and bottom of (7) by $\left[\bar{y}_{b}\left(\hat{k}_{c}\right) \quad \bar{y}_{b}\right.$ $\left.\left(\tilde{k}_{c}\right)\right]^{1 / 2}\left[\bar{y}_{c}\left(\hat{k}_{b}\right) \bar{y}_{c}\left(\tilde{k}_{b}\right)\right]^{1 / 2}$,

$$
\frac{y_{c}}{y_{b}}=\mathrm{EFF} \times\left(T E C H^{b} \cdot T E C H^{c}\right)^{1 / 2} \times\left(K A C C^{b} \cdot K A C C^{c}\right)^{1 / 2} \times\left(H A C C^{b} \times\right.
$$

$$
\left.\times H_{A C C}\right)^{1 / 2}=\mathrm{EFF} \times \mathrm{TECH} \times \mathrm{KACC} \times \mathrm{HACC}
$$

The data for empirical analysis is taken from the Penn World Table 7.1 and UNESCO Institute for Statistics (UIS). Aggregate output (real GDP) is calculated by multiplying income per capita (RGDPCH) by population size (POP) in the Penn Tables. Data on labour force is obtained by dividing real GDP by real GDP per worker (RGDPWOK) from the PWT 7.1. Physical capital stock is derived based on investment data (real) from the PWT 7.1 using the perpetual inventory method with an assumed depreciation rate of 6 percent for all countries. ${ }^{9}$ Following Barro (1991) and Barro and Lee (1993) the stock of human capital has been proxied by school enrolment rates. Data on total gross enrolment ratios has been retrieved from UIS since 2000 onwards due to a limited availability of data for earlier years for a larger sample of countries.

\section{Model I. Labour Measured as "Total Number of Hours Worked"}

The model points to significant contributions of technological progress and capital in the production process since 1995, both in absolute values and compared to Germany and the US (see Table 1). The exception are the last years since 2008 for technological progress, when the global crisis began. From 1995 to 2010, the average annual capital contribution in the four countries under discussion was $1.7 \%$, which was two times the average value for the advanced western economies. Similar results have been obtained for the total factor productivity input (an average of $1.8 \%$ for the CEEC-4 in 19952010), with its contribution recording higher values in the first half of the

${ }^{9}$ The initial level of capital stock $K_{0}$ is estimated as follows: $K_{0}=I_{0} /(\mathrm{g}+\varphi)$, where $\mathrm{g}$ is calculated as the average geometric growth rate of the investment series, $I_{0}$ is the value of the first observed investment level, and $\varphi$ is a depreciation rate. Next, stocks of capital are calculated using the following formula: $K_{T}=(1-\varphi)^{T} \cdot K_{0}+\sum_{t=0}^{T-1} I_{t}(1-\varphi)^{t}$ for $\forall \mathrm{t}$ in the sample. 
observation period. The average TFP growth in 1995-2002 was $2.1 \%$, while in 2003-2010 it was about $1.5 \%$. High TFP figures capture a more efficient use of production inputs and better managerial practices introduced with the transition process involving privatization, deregulation in product and labour markets, opening to international trade, foreign direct investment inflows and transfer of technologies. Therefore, the CEEC-4 were benefiting from a structural transformation in their economies. The opposite results, however, have been obtained for the labour input factor. The labour contribution in the CEEC-4 since 1995 was very weak or negative, which is a distinctive characteristic of the growth path in the Central Eastern Europe since the beginning of its economic transformation. The negative growth contribution from labour was the most significant in 1995-2000, with an average of $-0.4 \%$. It can be explained with the disorganization argument by Blanchard and Kremer (1997). Employment rates fell sharply during the 1990s with the privatization of state-owned enterprises, weak job-search incentives, and retraining for the new market economy due to social benefits and disability pensions (Estevão 2003; Schiff et. al. 2006). In the four countries under examination, one could also observe an ongoing process of sectoral transformation from agriculture and heavy industry to higher productivity industries and services. This was accompanied by increasing mismatches between labour supply and job vacancies, and created labour market bottlenecks in many sectors (Arratibel et al. 2007, p. 36). The negative developments in the labour market were further aggravated by increased east-west migration after the EU accession (International Monetary Fund 2008, p. 67). ${ }^{10}$ Labour contribution in 1995-2010 was negative on average at $-0.1 \%$, so it was a decelerating factor in the growth process.

Additional results have been obtained from splitting up the observation period into three parts: 1995-2000, 2001-2006 and 2007-2010. The average TFP contribution was significantly lower (on average $0.1 \%$ ) in the years 2007-2010 due to the global crisis (Hungary and the Czech Republic recorded negative values). It was higher, however, in the years of 2001-2006 (3\%) compared to the second half of the 1990s $(1.9 \%)$. There are several reasons which may explain this. First, TFP is the residual of the Solow decomposition, so its value depends on labour and capital, the other two factor inputs. The labour contribution to growth was negative in the 1990s with an average of $-0.4 \%$. In the $1990 \mathrm{~s}$, labour was substituted by capital and, at the same time, the slackness of labour force - which was inherited under the centrallyplanned economies - was gradually removed. These developments made the production process much more efficient and boosted the TFP contribution in

${ }^{10}$ Along with the international flows of capital, the movement of labor across the borders of the European Union's new member states has been perceived as a feature of their income convergence process. 
the 2000s. A second argument to explain the high TFP growth was a more stable macroeconomic and political environment due to the EU accession of the CEEC-4 in 2004, which attracted foreign investors to make substantial greenfield investments and, thus, increased the capital stock. European integration played a supporting role in the catching-up process in the CEEC-4 (Čihák and Fonteyne 2009). ${ }^{11}$ This anchoring certainly facilitated substantial trade flows and inflows of foreign direct investment (FDI), which facilitated technology transfer. Low unit labour costs combined with a relatively high human capital endowment also made the region attractive to foreign investors. This led to rapid technology transfer, access to high-income markets and the possibility of integrating into cross-border production networks. Furthermore, the four economies showed evidence of significant qualitative upgrading of their industrial and export structures (Landesmann and Stehrer 2009; Fabrizio et al. 2007). Other factors in the growth patterns of the CEEC-4 included changes in sectoral and regional economic structures, which meant difficult adaptation processes in the short run, but which resulted in more forward-looking patterns of sectoral and regional growth (Römisch 2007).

With respect to the growth rates of output, in the years 1995-2000 Poland $(4.7 \%)$ and Slovakia (3.4\%) experienced the growth rates above the average of $3.3 \%$, whereas the Czech Republic $(2.1 \%)$ was below the average as a result of the recession caused by the Asian crisis in 1997. All four countries were, however, on the climbing growth path till the global financial and economic crisis, with Slovakia achieving in 2006 the highest growth rate $(10 \%)$ in the region since the transition. When the global crisis began, all the four countries, however, experienced a sharp contraction in growth rates in the years 2007-2010 (with Hungary experiencing the negative figure $-0.8 \%$ ) - with the exception of Poland which recorded high positive growth (3.7\%).

\footnotetext{
${ }^{11}$ The benefits included the accession to the common market and free trade, financial assistance via EU transfers, and labour force mobility. Equally important were benefits from closer institutional and financial integration with Western Europe. They were seen in growing trade volumes, low risk premia, larger capital inflows and the increasing use of foreign savings in the CEEC-4.
} 
Table 1. Solow Growth Accounting (Model I: Total Hours Worked)

\begin{tabular}{|c|c|c|c|c|c|}
\hline & & $\begin{array}{l}1995- \\
-2000\end{array}$ & $\begin{array}{l}2001- \\
-2006 \\
\end{array}$ & $\begin{array}{l}2007- \\
-2010\end{array}$ & $\begin{array}{l}1995- \\
-2010 \\
\end{array}$ \\
\hline \multirow{4}{*}{$\begin{array}{c}\text { Czech } \\
\text { Republic }\end{array}$} & GDP $\%$ & 2,0 & 5,0 & 0,7 & 2,8 \\
\hline & Capital contribution $\%$ & 1,4 & 1,6 & 1,5 & 1,5 \\
\hline & Labour contribution $\%$ & $-0,6$ & 0,3 & 0,0 & $-0,1$ \\
\hline & TFP $\%$ & 1,2 & 3,2 & $-0,8$ & 1,4 \\
\hline \multirow{4}{*}{ Hungary } & GDP $\%$ & 3,1 & 3,5 & $-0,8$ & 2,3 \\
\hline & Capital contribution $\%$ & 1,6 & 1,8 & 1,4 & 1,6 \\
\hline & Labour contribution $\%$ & 0,4 & $-0,2$ & $-0,6$ & $-0,1$ \\
\hline & TFP $\%$ & 1,0 & 1,9 & $-1,6$ & 0,7 \\
\hline \multirow{4}{*}{ Poland } & GDP $\%$ & 4,7 & 4,5 & 3,7 & 4,4 \\
\hline & Capital contribution $\%$ & 1,6 & 1,5 & 1,3 & 1,5 \\
\hline & Labour contribution $\%$ & $-0,8$ & 0,5 & $-0,2$ & $-0,2$ \\
\hline & TFP $\%$ & 3,9 & 2,6 & 2,5 & 3,1 \\
\hline \multirow{4}{*}{$\begin{array}{c}\text { Slovak } \\
\text { Republic }\end{array}$} & GDP $\%$ & 3,4 & 6,6 & 2,0 & 4,3 \\
\hline & Capital contribution $\%$ & 2,6 & 2,0 & 1,9 & 2,2 \\
\hline & Labour contribution $\%$ & $-0,6$ & 0,5 & $-0,2$ & $-0,1$ \\
\hline & TFP $\%$ & 1,5 & 4,2 & 0,3 & 2,2 \\
\hline \multirow{4}{*}{ Germany } & GDP $\%$ & 1,8 & 1,4 & 0,7 & 1,4 \\
\hline & Capital contribution $\%$ & 0,7 & 0,4 & 0,4 & 0,5 \\
\hline & Labour contribution $\%$ & $-0,1$ & $-0,1$ & 0,3 & 0,0 \\
\hline & TFP $\%$ & 1,2 & 1,1 & 0,1 & 0,9 \\
\hline \multirow{4}{*}{ USA } & GDP $\%$ & 3,8 & 2,6 & $-0,2$ & 2,3 \\
\hline & Capital contribution $\%$ & 1,2 & 0,9 & 0,7 & 1,0 \\
\hline & Labour contribution $\%$ & 0,8 & 0,6 & $-0,7$ & 0,3 \\
\hline & TFP $\%$ & 1,8 & 1,0 & $-0,2$ & 1,0 \\
\hline
\end{tabular}

Source: Author's calculations based on the OECD Economic Outlook and the GGDC Total Economy Database.

\section{Model II. Relative Contributions of Labour, Capital and TFP}

In this model - instead of looking at the absolute contributions of capital, labour and TFP - the "relative" contributions have been considered to find out the relative importance of each input in the production process. This also allows for a comparison of the relative importance of each factor input across the countries (Neuhaus 2006, p. 25). For this purpose, the contribution of each factor input has been related to GDP growth rates. The results presented in Table 2 show that capital contribution in 1995-2010 was a relatively more important factor in fostering growth in CEEC-4 countries, followed by TFP, while labour had negative impact on growth. Also interesting is the 
fact that within the group of CEEC-4 countries the pattern of the relative growth contributions of capital, labour and TFP was similar in the examined time frame.

Table 2. Solow Growth Accounting (Model II: Relative Contributions)

\begin{tabular}{|c|c|c|c|c|c|}
\hline & \multirow{2}{*}{$\begin{array}{c}1995- \\
-2000\end{array}$} & \multirow{2}{*}{$\begin{array}{c}2001- \\
-2006\end{array}$} & \multirow{2}{*}{$\begin{array}{c}\begin{array}{c}2007- \\
\mathbf{- 2 0 1 0}\end{array} \\
0,7\end{array}$} & \multirow{2}{*}{$\begin{array}{c}\mathbf{1 9 9 5 -} \\
\mathbf{- 2 0 1 0} \\
2,8\end{array}$} \\
\hline \multirow{4}{*}{$\begin{array}{c}\text { Czech } \\
\text { Republic }\end{array}$} & GDP \% & & & & \\
\hline & $\begin{array}{l}\text { Relative capital con- } \\
\text { tribution } \%\end{array}$ & 68,7 & 31,9 & 219,1 & 53,7 \\
\hline & $\begin{array}{c}\text { Relative labour con- } \\
\text { tribution } \%\end{array}$ & $-28,1$ & 5,2 & 4,5 & $-4,0$ \\
\hline & Relative TFP \% & 59,1 & 63,0 & $-121,1$ & 50,4 \\
\hline \multirow{4}{*}{ Hungary } & GDP $\%$ & 3,1 & 3,5 & $-0,8$ & 2,3 \\
\hline & $\begin{array}{c}\text { Relative capital con- } \\
\text { tribution } \%\end{array}$ & 53,5 & 51,1 & $-172,9$ & 72,3 \\
\hline & $\begin{array}{c}\text { Relative labour con- } \\
\text { tribution } \%\end{array}$ & 13,2 & $-5,3$ & 72,8 & $-2,8$ \\
\hline & Relative TFP $\%$ & 33,1 & 54,1 & 197,6 & 30,8 \\
\hline \multirow{4}{*}{ Poland } & GDP $\%$ & 4,7 & 4,5 & 3,7 & 4,4 \\
\hline & $\begin{array}{l}\text { Relative capital con- } \\
\text { tribution } \%\end{array}$ & 34,2 & 32,3 & 35,9 & 33,8 \\
\hline & $\begin{array}{c}\text { Relative labour con- } \\
\text { tribution } \%\end{array}$ & $-16,4$ & 10,4 & $-4,3$ & $-3,5$ \\
\hline & Relative TFP \% & 82,1 & 57,3 & 68,2 & 69,5 \\
\hline \multirow{4}{*}{$\begin{array}{l}\text { Slovak } \\
\text { Republic }\end{array}$} & GDP \% & 3,4 & 6,6 & 2,0 & 4,3 \\
\hline & $\begin{array}{c}\text { Relative capital con- } \\
\text { tribution } \%\end{array}$ & 75,0 & 29,9 & 96,1 & 51,4 \\
\hline & $\begin{array}{c}\text { Relative labour con- } \\
\text { tribution } \%\end{array}$ & $-18,2$ & 6,8 & $-9,3$ & $-2,6$ \\
\hline & Relative TFP \% & 43,5 & 63,3 & 15,6 & 51,7 \\
\hline \multirow{4}{*}{ USA } & GDP $\%$ & 3,8 & 2,6 & $-0,2$ & 2,3 \\
\hline & $\begin{array}{c}\text { Relative capital con- } \\
\text { tribution } \% \\
\end{array}$ & 31,0 & 36,7 & $-289,1$ & 42,0 \\
\hline & $\begin{array}{c}\text { Relative labour con- } \\
\text { tribution } \%\end{array}$ & 21,3 & 22,9 & 287,0 & 15,0 \\
\hline & Relative TFP \% & 47,8 & 40,3 & 99,9 & 43,4 \\
\hline \multirow{4}{*}{ Germany } & GDP $\%$ & 1,8 & 1,4 & 0,7 & 1,4 \\
\hline & $\begin{array}{c}\text { Relative capital con- } \\
\text { tribution } \% \\
\end{array}$ & 36,6 & 30,6 & 49,7 & 36,1 \\
\hline & $\begin{array}{c}\text { Relative labour con- } \\
\text { tribution } \%\end{array}$ & $-3,9$ & $-9,2$ & 40,4 & $-0,2$ \\
\hline & Relative TFP \% & 67,3 & 79,0 & 13,9 & 64,7 \\
\hline
\end{tabular}

Source: Author's calculations based on the OECD Economic Outlook and the GGDC Total Economy Database. 
Figure 2. Relative Contributions from Capital, Labour, and TFP to Economic Growth in the CEEC-4 between 1995-2010 (Model II)

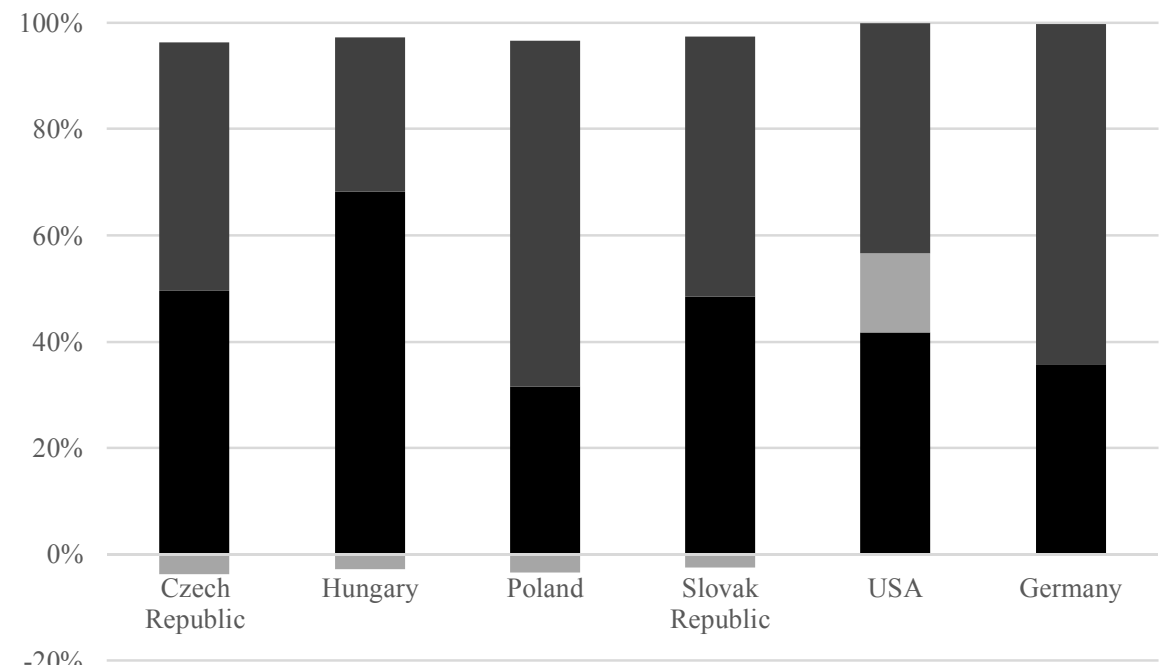

- Relative capital contribution \% $\quad$ Relative labour contribution \% $\quad$ Relative TFP \%

Source: Author's calculations based on the OECD Economic Outlook and the GGDC Total Economy Database.

\section{Quadripartite Decomposition}

The quadripartite decomposition has been conducted for two sub-periods: 2001-2006 (see Table 3) and 2007-2010 (see Table 4) to obtain a comparative basis with the results from the Solow growth accounting. ${ }^{12}$ It appears that productivity growth has been driven primarily by efficiency improvements (technological catch-up) and by human capital accumulation in the CEEC-4. This might indicate that the emerging economies of the Central Eastern Europe have already passed the phase common for developing countries, in which productivity growth is attributed mainly to technological change and physical capital accumulation. Higher efficiency in the use of inputs can be achieved by investment in "knowledge," which can be defined as investment in R\&D and higher education (Arratibel et al. 2007, p. 29). Poland in 2001-2006 and Hungary in 2007-2010 recorded the negative growth contributions from human capital accumulation. It could be explained with the largest outflow of skilled workers from Poland observed

${ }^{12}$ The calculations were conducted using the R software and IpSolve package. 
within the group of CEEC-4 in the aftermath of the EU accession, while in case of Hungary - with an outflow related to a recession caused by the economic crisis in 2007.

Table 3. Percentage change of quadripartite decomposition indexes, 2001-2006

\begin{tabular}{|l|c|c|c|c|c|}
\hline \multicolumn{1}{|c|}{ Country } & $\begin{array}{c}\text { Productivity } \\
\text { change }\end{array}$ & EFF & TECH & KACC & HACC \\
\hline Argentina & 10.1 & 2.7 & 5.4 & 0.1 & 1.6 \\
\hline Armenia & 81.7 & 76.5 & 6.5 & -1.8 & -1.5 \\
\hline Australia & 8.5 & 13.4 & 5.4 & -2.7 & -6.6 \\
\hline Austria & 8.5 & 3.2 & 5.5 & 0.8 & -1.2 \\
\hline Belgium & 5.2 & 15.0 & 5.2 & 1 & -14 \\
\hline Bulgaria & 31.7 & 26.1 & 6.7 & 1.1 & -3.2 \\
\hline Czech Republic & 26.9 & 9.4 & 5.1 & 2.0 & 8.2 \\
\hline Estonia & 42.7 & 30.9 & 8.0 & 0.0 & 0.9 \\
\hline Finland & 13.8 & 8.8 & 5.4 & 3.1 & -3.8 \\
\hline France & 5.2 & -4.3 & 5.5 & 0.3 & 4 \\
\hline Hungary & 19.1 & 2.0 & 5.2 & 2.0 & 8.8 \\
\hline Iceland & 12.1 & -2.1 & 8.0 & 0.0 & 6.0 \\
\hline Indonesia & 13.9 & 55.5 & 48.1 & -52.2 & 3.5 \\
\hline Ireland & 8.4 & -6.1 & 6.4 & 2.6 & 5.7 \\
\hline Israel & 3.9 & -9.2 & 5.0 & 0.9 & 8.0 \\
\hline Japan & 9.7 & 0.7 & 5.5 & 0.1 & 3.2 \\
\hline Kazakhstan & 73.6 & 52.4 & 5.2 & -3.2 & 11.8 \\
\hline Republic of Korea & 17.5 & 5.2 & 5.5 & 0.6 & 5.3 \\
\hline Lithuania & 50 & 34.6 & 7.3 & 0.8 & 3.1 \\
\hline Mexico & 2.0 & -9.8 & 1.2 & 5.1 & 6.3 \\
\hline Netherlands & 2.7 & 25.5 & 47.8 & -44.3 & -0.7 \\
\hline New Zeland & 7.0 & -3.2 & 6.6 & -3.9 & 7.9 \\
\hline Norway & 9.9 & 0.0 & 6.4 & 1.5 & 1.7 \\
\hline Poland & 25.7 & 20.5 & 5.3 & 0.5 & -1.5 \\
\hline Portugal & -1.7 & -5.9 & 5.1 & 1.0 & -1.6 \\
\hline Romania & 55.4 & 28.7 & 5.4 & 1.2 & 13.2 \\
\hline Slovak Republic & 30.9 & 18.7 & 6.6 & -4.2 & 8.0 \\
\hline Slovenia & 18.0 & 11.8 & 6.6 & -3.7 & 2.9 \\
\hline Spain & -1.7 & -11.1 & 5.5 & 0.4 & 4.4 \\
\hline Sweden & 13.9 & 25.7 & 5.1 & 1.7 & -15.3 \\
\hline Switzerland & 4.5 & -2.1 & 5.4 & 0.8 & 0.5 \\
\hline Ukraine & 49.4 & 38.5 & 5.5 & 0.3 & -1.0 \\
\hline United Kingdom & 6.4 & 1.6 & 5.5 & 0.3 & -1.0 \\
\hline United States & 8.3 & -4.0 & -0.7 & 6.5 & 2.4 \\
\hline Uruguay & & & & \\
\hline & 9.4 & & & & \\
\hline & & & & & \\
\hline
\end{tabular}

Source: Author's calculations based on Penn World Table 7.1 and UNESCO Institute for Statistics databases. 
Table 4. Percentage change of quadripartite decomposition indexes, 2007-2010

\begin{tabular}{|l|c|c|c|c|c|}
\hline \multicolumn{1}{|c|}{ Country } & $\begin{array}{c}\text { Productivity } \\
\text { change }=\end{array}$ & EFF & TECH & KACC & HACC \\
\hline Argentina & 13.4 & 13.4 & -5.3 & 0.2 & 5.4 \\
\hline Armenia & -2.6 & -5.2 & -3.0 & 3.8 & 2.0 \\
\hline Australia & 0.9 & 1.5 & -5.7 & 0.7 & 4.6 \\
\hline Austria & -1.1 & -1.6 & -3.9 & 0.5 & 4.1 \\
\hline Belgium & -1.5 & 1.0 & -4.1 & 0.4 & 1.2 \\
\hline Bulgaria & 4.6 & 17.4 & -3.6 & -9.7 & 2.4 \\
\hline Czech Republic & 2.5 & 3.5 & -4.4 & 0.8 & 2.7 \\
\hline Estonia & -10.9 & -9.7 & -2.0 & 0.0 & 0.7 \\
\hline Finland & -5.8 & -2.5 & -3.8 & 1.3 & -0.8 \\
\hline France & -2.2 & 2.6 & -5.6 & 0.2 & 0.8 \\
\hline Hungary & -5.2 & -1.3 & -4.7 & 1.0 & -0.2 \\
\hline Iceland & -17.0 & -17.1 & -2.0 & 0.0 & 2.1 \\
\hline Indonesia & 14.8 & -37.3 & 19.6 & 53.0 & 0.0 \\
\hline Ireland & -12.8 & -15.0 & -3.6 & 1.1 & 5.3 \\
\hline Israel & 1.6 & 6.0 & -4.0 & 0.5 & -0.6 \\
\hline Japan & -3.4 & 3.8 & -16.1 & 10.1 & 0.7 \\
\hline Kazakhstan & 14.1 & 21.3 & -5.3 & 1.0 & -1.7 \\
\hline Republic of Korea & 8.8 & 13.7 & -5.6 & 0.1 & 1.3 \\
\hline Lithuania & -12.2 & -9.3 & -2.0 & 0.0 & -1.2 \\
\hline Mexico & -7.5 & -4.4 & -5.7 & 0.0 & 2.6 \\
\hline Netherlands & -0.3 & -14.0 & -12.9 & 31.4 & 1.4 \\
\hline New Zeland & -1.1 & 1.8 & -4.7 & 1.7 & 0.1 \\
\hline Norway & -2.7 & 0.0 & -2.7 & 0.7 & -0.6 \\
\hline Poland & 7.5 & 134.4 & 6.6 & -57.3 & 0.8 \\
\hline Portugal & -3.0 & -3.7 & -4.5 & 0.4 & 5.1 \\
\hline Romania & -0.3 & 0.5 & -5.2 & 0.7 & 3.8 \\
\hline Slovak Republic & 3.1 & 5.4 & -4.8 & 0.9 & 1.8 \\
\hline Slovenia & -3.9 & -3.8 & -4.5 & 2.2 & 2.3 \\
\hline Spain & -8.4 & -8.7 & -5.6 & 0.3 & 6.0 \\
\hline Sweden & -1.1 & 3.3 & -4.4 & 0.6 & -0.5 \\
\hline Switzerland & 1.3 & 3.3 & -4.0 & 0.4 & 1.7 \\
\hline Ukraine & -1.3 & 2.3 & -5.6 & 0.2 & 2.0 \\
\hline United Kingdom & -4.1 & -2.4 & -5.6 & 0.0 & 4.2 \\
\hline United States & 0.0 & -7.6 & 2.8 & 2 \\
\hline Uruguay & 23.1 & -2.0 & 0.0 & -2.3 \\
\hline
\end{tabular}

Source: Author's calculations based on Penn World Table 7.1 and UNESCO Institute for Statistics databases. 


\section{Conclusions}

In conclusion, the growth accounting approach provides evidence that capital and TFP contributions were the most significant growth inputs in the CEEC-4 during the years 1995-2010. At the country level, capital contribution was most distinct in the case of Slovakia, while TFP - in Poland. For all four Central Eastern European countries the contributions of those two factor inputs - capital and TFP - were higher in the growth process compared to advanced western economies. Furthermore, the four transition economies experienced a strong decline in labour input compared to the advanced western countries. This effect was the most significant in Poland. Before the global crisis, all CEEC-4 countries experienced significantly higher growth rates than Western European countries, which can be explained with a convergence process known in the literature as ' $\beta$-convergence'. ${ }^{13}$ As lowerincome and lower-productivity economies, the CEEC-4 benefited from technology transfer, which was the main driver behind the catching-up process.

The non-parametric approach provides a valuable insight into human capital accumulation process in the economy and its contribution to growth. As the endogenous growth theory emphasises the quality of factor inputs and introduces the notion of human capital pointing to the importance of knowledge-based economy, the aim of my further research is to examine the CEEC-4's potential for knowledge-based growth. As a knowledge-based growth path gives a country a greater ability to adapt to technological change and globalisation, my analysis may shed some light on the CEEC-4 countries' post-crisis prospects as they try to follow more sustainable and robust growth paths.

\section{References}

Aghion P., Howitt P. (1998), Endogenous Growth Theory, The MIT Press, Cambridge.

Arratibel O., Heinz F., Martin R., Przybyla M., Rawdanowicz L., Serafini R., Zumer T. (2007), Determinants of Growth in the Central and Eastern European EU Member States - A Production Function Approach, "ECB Occasional Papers Series", No. 61, Frankfurt am Main.

Åslund A. (2007), How Capitalism Was Built: The Transformation of Central and Eastern Europe, Russia and Central Asia, Peterson Institute for International Economics, Washington.

${ }^{13}$ It stems from the convergence hypothesis of the neoclassical growth literature and it occurs when poor economies grow faster than rich ones. 
Bakker B., Klingen C. (2012), How Emerging Europe Came Through the 2008/09 Crisis: An Account by the Staff of the IMF's European Department, International Monetary Fund, Washington.

Blanchard O., Kremer M. (1997), Disorganization, “The Quarterly Journal of Economics", Vol. 112, No. 4, http://dx.doi.org/10.1162/003355300555439.

Čihák M., Fonteyne W. (2009), Five Years After: European Union Membership and Macro-Financial Stability in the New Member States, "IMF Working Paper", March 2019, WP/09/68, Washington.

Commission on Growth and Development (2008), The Growth Report: Strategies for Sustained Growth and Inclusive Development, World Bank, Washington.

Estevão M. (2003), Structural and Cyclical Labor Market Changes in Poland: Selected Issues, IMF Country Report No. 03/188, Washington.

Fabrizio S., Leigh D., Mody A. (2007), The Dynamics of Product Quality and International Competitiveness, "IMF Working Paper" WP/07/09, Washington.

Farrell M.J., (1957), The measurement of productive efficiency, "Journal of the Royal Statistical Society", Vol. 120, http://dx.doi.org/10.2307/2343100.

Färe R., Grosskopf S., Norris M., Zhang, Z. (1994), Productivity growth, technical progress and efficiency changes in industrialised countries, "American Economic Review", Vol. 84.

Henderson D., Russell R. (2005), Human Capital and Convergence: A ProductionFrontier Approach, "International Economic Review", Vol. 46, http://dx.doi.org/10.1111/j.1468-2354.2005.00364.x.

International Monetary Fund (2008), Regional Economic Outlook, Europe: Dealing with Shocks, "IMF World Economic and Financial Surveys", October, Washington.

Iradian G. (2007), Rapid Growth in the CIS: Panel Regression Approach, "IMF Working Paper", WP/07/170, July 2007, Washington.

Kumar, S., Russell R. (2002), Technological change, technological catch-up, and capital deepening: Relative contributions to growth and convergence, "American Economic Review", Vol. 92, No. 3, http://dx.doi.org/10.1257/0002828 0260136381.

Landesmann M. A., Stehrer R. (2009), Trade and Growth: 'South-North' Integration, Outsourcing and Skills [in:] P. Mooslechner, R. Kronberger, M.A. Landesmann (eds.), International Trade and Domestic Growth: Determinants, Linkages and Challenges, Austrian National Bank, Vienna.

Neuhaus M. (2006), The Impact of FDI on Economic Growth. An Analysis for the Transition Countries of Central and Eastern Europe, Physica-Verlag A Springer Company.

Römisch R. (2007), Changing Regions - Structural Changes in EU Regions, Study carried out for DG Regional Policy by Applica and wiiw.

Schiff J. A., Egoumé-Bossogo P., Ihara M., Konuki T., Krajnyák K. (2006), Labor Market Performance in Transition: The Experience of Central and Eastern Europe, "IMF Occasional Paper", No. 248, Washington.

Solow R.M., Tobin J., von Weizsacker C., Yaari M., (1966), Neoclassical Growth with Fixed Factor Proportions, "Review of Economic Studies", Vol. XXXIII, No. 2, http://dx.doi.org/10.2307/2974435. 
Solow R.M. (1962), Substitution and Fixed Proportions in the Theory of Capital, "Review of Economic Studies", Vol. 29, No. 3, http://dx.doi.org/10.2307/2295955.

Solow R.M. (1957), Technical Change and the Aggregate Production Function, "Review of Economics and Statistics", Vol. 39, No. 3, http://dx.doi.org/10.2307 1926047.

Solow R.M. (1956), A Contribution to the Theory of Economic Growth, "Quarterly Journal of Economics", Vol. 70, No. 1, http://dx.doi.org/10.2307/1884513.

Swan T.W. (1956), Economic Growth and Capital Accumulation, "Economic Record", Vol. 32, No. 2, http://dx.doi.org/10.1111/j.1475-4932.1956.tb00434.x.

Thörnqvist L. (1936), The Bank of Finland's Consumption Price Index, "Bank of Finland Monthly Bulletin", No. 10. 